\title{
INVESTIGATION OF ACTIVITY AND SELECTIVITY OF REDOX CATALYSTS IN OXIDATIVE COUPLING OF METHANE IN FLUIDIZED BED REACTOR
}

\author{
M. Bayanak* and A. Azimi \\ Mahshahr Branch, Islamic Azad University, Mahshahr, Iran
}

Published online: 15 May 2016

\begin{abstract}
In this study, oxidative coupling of methane on Redox catalysts in fluidized bed reactor was investigated. For this purpose, the catalyst $\mathrm{Mn}-\mathrm{Na}_{2} \mathrm{WO}_{4} / \mathrm{SiO}_{2}$ was selected as a Redox catalyst. In order to investigate this catalyst, transient state experiments were designed and performed. Then, the different reaction conditions on this catalyst in a fluidized bed reactor were investigated. In transient state experiments, methane feed without the presence of oxygen in the gas phase was sent incrementally on the catalyst and oxidative coupling of methane was examined. Reactor output was analyzed by two systems of GC and GC-MS. The effect of different operational temperatures on the amount of production of coupling products showed that the catalyst has Redox features. With increasing catalyst bed temperature, mobility of oxygen in network increases, which leads to an increase in production. Reoxidation of catalyst bed with oxygen and repeating the experiment and the results confirmed the property of redox catalyst. Then, transient state experiments at temperatures of 800 and $850{ }^{\circ} \mathrm{C}$ were repeated with the same conditions and the percentage of methane conversion, selectivity, and mole percent of components were investigated. It was observed that at first, methane conversion is high and then as the oxygen of the catalyst and the speed decrease, methane conversion decreases dramatically. According to the chart of mole composition, when the conversion rate is high, the main products of coupling reaction are $\mathrm{C}_{2} \mathrm{H}_{6}, \mathrm{C}_{2} \mathrm{H}_{4}$ is.
\end{abstract}

Author Correspondence, e-mail: m_bayanak2003@yahoo.com

doi: http://dx.doi.org/10.4314/jfas.v8i3s.189 
Keywords: Oxidative coupling of methane; fluidized bed reactor; redox catalyst; transient state.

\section{INTRODUCTION}

Methane is the main component of natural gas and is used as a clean fuel and relatively inexpensive one today. The huge volume of natural gas in the world $17 \%$ of which is produced in Iran, as well as high economic advantages of converting methane to other fuels o more valuable chemicals has encouraged many research studies on methods of converting methane to liquid hydrocarbon fuels, ethylene, methanol, and so on. In addition, because natural gas transmission to distant

Centers is expensive, methane conversion to intermediate petrochemical materials and liquid hydrocarbons known as OCM and GTL processes, has always been of utmost importance.

Natural gas, at the beginning of the third millennium, was the world's second source of cheap energy. Its abundance and relative availability were compelling reasons to develop research on this source. On the other hand, the global need for methanol and ethylene as two desirable major products resulting from the conversion of natural gas is increasing every day and the possibility of producing ethylene from methane has attracted the attention of numerous academic and industrial research centers. Methane with binding energy of $105 \mathrm{kcal} / \mathrm{mol} \mathrm{C}-\mathrm{H}$ is one of the most stable alkanes. Because methane is expected to form the next major source of chemicals, despite the stability of the molecule, many studies have been done in putting this molecule in chemical reactions. Extensive research has been conducted in the last two decades on the direct conversion of methane to ethylene, ethane, formaldehyde, methanol, etc. Methane conversion to other chemicals is done by two general methods: direct and indirect.

\section{OXIDATIVE COUPLING OF METHANE}

Oxidative coupling of methane is a process in which the feed (methane molecule) is much more stable than coupling products (ethane and ethylene) and intermediate materials (methyl radical). Therefore, active and selective catalyst design is a big challenge in the field of heterogeneous catalysts. The main objective of the process of OCM is conversion of methane to ethylene. Because methane coupling with dehydration is an undesirable process in terms of endothermic energy and it should occur at very high temperatures, it should be done in the presence of oxygen to be done at lower temperatures (oxidative coupling of methane). Therefore, the undesirable side products i.e. carbon oxides are also formed non-selectively. 


$$
\begin{array}{ll}
2 \mathrm{CH}_{4} \rightarrow \mathrm{C}_{2} \mathrm{H}_{6}+\mathrm{H}_{2} & \therefore \Delta \mathrm{G}_{298}^{0}=69 \mathrm{kj} / \mathrm{mol} \\
2 \mathrm{CH}_{4}+0.5 \mathrm{O}_{2} \rightarrow \mathrm{C}_{2} \mathrm{H}_{6}+\mathrm{H}_{2} \mathrm{O} & \therefore \Delta \mathrm{G}_{298}^{0}=-160 \mathrm{kj} / \mathrm{mol}
\end{array}
$$

Methane conversion to unwanted products of carbon oxides decreases hydrocarbon yields (Y). In addition, the formation of carbon dioxide, which is highly exothermic, causes technical problems in the commercialization process. Almost all studies in this field aim at production of ethane and ethylene with high selectivity with proper conversion of methane (C) during a stage of passing through a catalyst system.

\section{REACTION MECHANISM}

In terms of mechanism of OCM, there are two major ideas for the activation of $\mathrm{C}-\mathrm{H}$ bond in methane: homogeneous and heterogeneous detachment of the bond [1]. In homogeneous detachment, methane molecule combines with an activated form of oxygen on the surface of the catalyst and produces methyl radical. This radical, in turn, combines with similar radicals and converts into ethane and higher things. In heterogeneous detachment, methane reaction on the catalyst surface is done in the form of acid-base reaction. In this reaction, radical is formed indirectly. Mechanisms of heterogeneous detachment of $\mathrm{C}-\mathrm{H}$ bond are approved. However, there are cases which cannot be explained by this mechanism. The adopted mechanism for methane oxidative coupling mechanism is heterogeneous Homogeneous mechanism. Under this mechanism, methane is activated on the surface of the catalyst by surface oxygen species (surface network oxygen or oxygen adsorbed on the surface), resulting in the formation of methyl radicals and surface hydroxyl species [1]:

$2 \mathrm{CH}_{3}^{\bullet} \rightarrow \mathrm{C}_{2} \mathrm{H}_{6}$

Methyl radicals produce $\mathrm{CO}_{\mathrm{X}}$ through a series of chain reactions in the gas phase:

$$
\begin{aligned}
& \mathrm{CH}_{3}^{\bullet}+\mathrm{O}_{2} \longleftrightarrow \mathrm{CH}_{3} \mathrm{O}_{2}^{\bullet} \\
& \mathrm{CH}_{3} \mathrm{O}_{2}^{\bullet}+\mathrm{C}_{2} \mathrm{H}_{6} \rightarrow \mathrm{CH}_{3} \mathrm{O}_{2} \mathrm{H}+\mathrm{C}_{2} \mathrm{H}_{5}^{\bullet} \\
& 2 \mathrm{CH}_{3} \mathrm{O}_{2}^{\bullet} \rightarrow \mathrm{CH}_{2} \mathrm{O}+\mathrm{CH}_{3} \mathrm{OH}+\mathrm{O}_{2} \rightarrow \mathrm{CO}, \mathrm{CO}_{2} \\
& \mathrm{CH}_{3} \mathrm{O}_{2} \mathrm{H} \rightarrow \mathrm{CH}_{3} \mathrm{O}^{\bullet}+\mathrm{OH}^{\bullet} \\
& \mathrm{CH}_{3} \mathrm{O}^{\bullet}+\mathrm{CH}_{4} \rightarrow \mathrm{CH}_{3} \mathrm{OH}+\mathrm{CH}_{3} \\
& \mathrm{OH}^{\bullet}+\mathrm{CH}_{4} \rightarrow \mathrm{CH}_{3} \cdot \mathrm{H}_{2} \mathrm{O}
\end{aligned}
$$

Or on the surface:

$$
\mathrm{CH}_{3}{ }^{\cdot}+\mathrm{O}^{2-}(\text { surface }) \rightarrow \mathrm{CH}_{3} \mathrm{O}^{-}+e^{-}
$$


$\mathrm{CH}_{3} \mathrm{O}^{-} \rightarrow \mathrm{CH}_{3} \mathrm{OH}, \mathrm{CH}_{2} \mathrm{O} \rightarrow \mathrm{CO}, \mathrm{CO}_{2}$

The ethane produced in the coupling reaction tends to produce ethylene at the level of catalyst:

$\mathrm{C}_{2} \mathrm{H}_{6}+\left[\mathrm{M}^{+} \mathrm{O}^{-}\right] \rightarrow \mathrm{C}_{2} \mathrm{H}_{5}^{\bullet}+\left[\mathrm{M}^{+} \mathrm{OH}^{-}\right]_{s}$

$\mathrm{C}_{2} \mathrm{H}_{5}^{\cdot}+\mathrm{O}^{2-} \rightarrow \mathrm{C}_{2} \mathrm{H}_{5} \mathrm{O}^{-}+e^{-}$

$\mathrm{C}_{2} \mathrm{H}_{5} \mathrm{O}^{-} \rightarrow \mathrm{C}_{2} \mathrm{H}_{4}+\mathrm{OH}^{-}$

$\mathrm{CH}_{3}^{\bullet}+\mathrm{C}_{2} \mathrm{H}_{6} \rightarrow \mathrm{CH}_{4}+\mathrm{C}_{2} \mathrm{H}_{5}^{\bullet}$

$\mathrm{C}_{2} \mathrm{H}_{5}^{\bullet} \rightarrow \mathrm{C}_{2} \mathrm{H}_{4}+\mathrm{H}^{\bullet}$

$\mathrm{C}_{2} \mathrm{H}_{5}^{\cdot}+\mathrm{O}_{2} \rightarrow \mathrm{C}_{2} \mathrm{H}_{4}+\mathrm{HO}_{2}^{\cdot}$

Since the reaction products of OCM are often more active than methane, they may create other radicals which may create even more radicals by reactions in the gas phase or at the surface. These intermediate products have a high tendency to oxidize and ultimately produce COx products. Since OCM reaction effectively proceeds only at temperatures above $900 \mathrm{~K}$, the reaction of oxygen with methane, $\mathrm{C}_{2}$ products, methyl radical in the gas phase, and catalytic reactions at the surface become important.

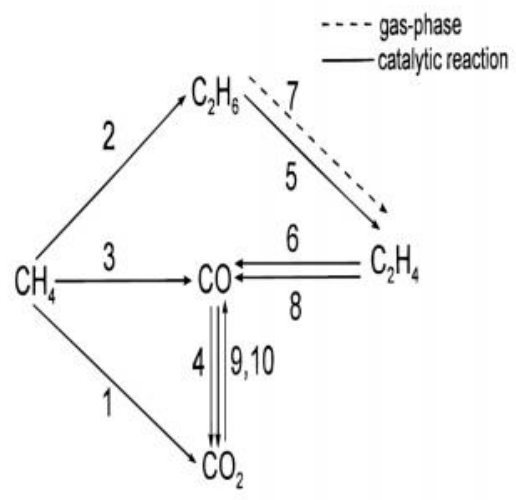

Fig.1. OCM heterogeneous reaction network based on the proposed model Mleczko and Stansch [4]

Step 1: $\quad \mathrm{CH}_{4}+2 \mathrm{O}_{2} \rightarrow \mathrm{CO}_{2}+2 \mathrm{H}_{2} \mathrm{O}$

Step 2: $\quad 2 \mathrm{CH}_{4}+0.5 \mathrm{O}_{2} \rightarrow \mathrm{C}_{2} \mathrm{H}_{6}+\mathrm{H}_{2} \mathrm{O}$

Step 3: $\quad \mathrm{CH}_{4}+\mathrm{O}_{2} \rightarrow \mathrm{CO}+\mathrm{H}_{2} \mathrm{O}+\mathrm{H}_{2}$

Step 4: $\mathrm{CO}+0.5 \mathrm{O}_{2} \rightarrow \mathrm{CO}_{2}$

Step 5: $\quad \mathrm{C}_{2} \mathrm{H}_{6}+0.5 \mathrm{O}_{2} \rightarrow \mathrm{C}_{2} \mathrm{H}_{4}+\mathrm{H}_{2} \mathrm{O}$ 
Step 6: $\quad \mathrm{C}_{2} \mathrm{H}_{4}+2 \mathrm{O}_{2} \rightarrow 2 \mathrm{CO}+2 \mathrm{H}_{2} \mathrm{O}$

Step 7: $\quad \mathrm{C}_{2} \mathrm{H}_{6} \rightarrow \mathrm{C}_{2} \mathrm{H}_{4}+\mathrm{H}_{2}$

Step 8: $\quad \mathrm{C}_{2} \mathrm{H}_{4}+2 \mathrm{H}_{2} \mathrm{O} \rightarrow 2 \mathrm{CO}+4 \mathrm{H}_{2}$

Step 9: $\mathrm{CO}+\mathrm{H}_{2} \mathrm{O} \rightarrow \mathrm{CO}_{2}+\mathrm{H}_{2}$

Step 10: $\quad \mathrm{CO}_{2}+\mathrm{H}_{2} \rightarrow \mathrm{CO}+\mathrm{H}_{2} \mathrm{O}$

Using different catalysts, Santamaria et.al in their research on OCM reaction concluded that the OCM reaction and the kinetic model of the reaction is a function of the type of catalyst and its composition [5]. Among the best and most complete kinetic equations presented so far, the equations provided by Z.Stansch et.al [4], Santamaria et.al [5], Chaouki et al [6], and Zanthoff et.al [7] can be mentioned.

\section{OXIDATIVE COUPLING CATALYSTS OF METHANE}

The most appropriate classification for OCM catalysts is presented by Lee and Oyama [8]. All catalyst are divided into two categories: reducing metallic oxides and non-reducing metallic oxides. Reducing catalysts are mostly appropriate for OCM operations periodically by intermittent feeding of raw materials of the reaction (methane and oxygen). For such a mechanism, Redox catalysts is proposed. Irreducible oxides show the best results for OCM operations in simultaneous and combined feeding method. For these catalysts, radical mechanism is proposed. It is assumed that $\mathrm{O}_{2}$ - network oxygen is an active center for catalysts of the first group while O-species are active centers for catalysts of the second group. Oxides of rare earth elements (REE) that are close to the irreducible oxides (except $\mathrm{Pr}, \mathrm{Ce}$ and $\mathrm{Tb}$ ) were diagnosed separately. The species with two oxygen atoms $\left(\mathrm{O}_{2}^{2-}, \mathrm{O}_{2-}\right)$ are assumed to be active centers for rare earth oxides (REE). In some references, these catalyst are similar to reducible oxides. Anyway, high dynamism of network oxygen in oxygen conductor ions and controlling the mobility by electrocatalytic methods may answer the questions about the nature of active oxygen sites for OCM reaction.

Since Lunsford et al. [9] first showed that lithium sitting on a magnesium oxide is an active and selective catalyst for the oxidative coupling reaction, alkali metallic catalysts sitting on alkaline earth metals have been studied by many researchers. Testing a number of metal oxides, Keller and Bhasin [2] found out that metal oxides show activity for coupling reaction. 


\section{OCM REACTORS}

As previously mentioned, OCM reaction suffers from low yields and selectivity of $\mathrm{C}_{2}$ for industrialization. On the other hand, in addition to the type of catalyst, the condition and shape of the reactor and the kind of operation play an important role in producing ethylene with high yield and high selectivity. Most studies having been conducted so far assess the activity of the catalyst in a fixed bed reactor. Given that OCM reactions have been considered both homogeneous and heterogeneous in studies, the role of process parameters and the type of reactor used will be critical. Due to this fact, in different studies, various reactors such as fixed bed reactor, Membrane Reactor, Corona Reactor, Reverse Flow Reactor, Counter Current Moving Bed Reactor, and fluidized bed reactor have been studied in order to evaluate the overall performance of reactor for OCM reaction.

Studies related to the conversion of methane to ethane and ethylene in the presence of oxygen for kinetics investigations and industrial purposes are mostly carried out in three reactors:

- Fixed bed reactor

- Membrane reactor

- Fluidized bed reactor

\section{REVIEWING THE MECHANISM AND THE MOST IMPORTANT WORKS DONE}

A major problem for the industrialization of OCM is that it is a highly exothermic reaction. Therefore, the reaction should occur in a reactor which is able to harness large amounts of released heat in order to both maintain process safety and guarantee high selectivity of hydrocarbon products. Among the reactors commonly used for exothermic reactions, fluidized bed reactor is a good option that has been studied by researchers. However, many active and selective OCM catalysts such as $\mathrm{Li} / \mathrm{MgO}, \mathrm{NaOH} / \mathrm{CaO}, \mathrm{Na} 2 \mathrm{SO} 4 / \mathrm{CaO}$ do not show sufficient mechanical strength like Sm2O3. Moreover, since OCM involves a complex network of reactions, selectivity and yield of $\mathrm{C}^{2+}$ does not depend only on the catalyst. It also depends on the type of reactor and operating conditions and is affected by hydrodynamic fluid bed reactor.

In the work done in the field of fluidized bed reactors, two major objectives have usually been pursued:

1) Fluid ability and mechanical stability of the catalyst

2) Determining the operating conditions that lead to maximum efficiency and high selectivity relative to the hydrocarbon products. 
The optimal reaction conditions is a special desired target as efficiency and selectivity of $\mathrm{C}^{2+}$ not only depend on the temperature and the partial pressure of reactants but also are often influenced by gas blend, porosity, and mass transfer between bubble phase and emulsion.

To follow the above objectives, after selecting the catalyst, minimum fluid velocity of the catalyst with nitrogen is usually measured at temperatures near OCM reaction temperature. For example, for catalyst $\mathrm{Zr} / \mathrm{La} / \mathrm{Sr}$, minimum fluid velocity at $600^{\circ} \mathrm{C}$ is $0.018 \mathrm{~m} / \mathrm{s}$. Then, short and shallow fluidized bed is selected to achieve a sustainable flow. Having examined the velocity and mechanical stability, different factors affecting the performance of a fluidized bed reactor in the process of oxidative coupling of methane are discussed. These factors include temperature, gas feed composition (ratio of methane to oxygen or the presence of inert gas), the effect of gas velocity, bed height, and size of catalyst particles.

\section{THE EFFECT OF TEMPERATURE AND COMPOSITION OF FEED}

Unlike in fixed bed reactor, in order to manage heat released by the OCM reaction, diluting the feed is not necessary. Recovery of $\mathrm{C}^{2+}$ selectivity and yield by diluting the feed in fluidized bed has often been reported for catalyst $\mathrm{PbO} / \gamma-\mathrm{Al}_{2} \mathrm{O}_{3}$. This effect can be explained by nonlinear dependence of selective and non-selective elementary stages of reaction on partial pressure of methane and oxygen. However, increasing the efficiency and selectivity of $\mathrm{C}^{2+}$ when the feed is diluted is generally not valid. For example, for $\mathrm{La}_{2} \mathrm{O}_{3} / \mathrm{CaO}$, dilution of the feed had no effect on $\mathrm{C}^{2+}$ selectivity when the reaction was performed in a fluidized bed. $\mathrm{C}^{2+}$ selectivity increase with temperature can be explained by higher activation energy of the selective reaction stage compared to non-selective stages. The kinetics effects are visible for the majority of OCM catalysts. However, increasing the selectivity of $\mathrm{C}^{2+}$ at temperatures higher than $860^{\circ} \mathrm{C}$ has been observed in fluidized bed reactors [35]. For other OCM catalysts that have been used in this type of reactor, selectivity passes from a maximum value at a lower temperature. The maximum temperature depends on the catalyst and reaction conditions. The temperature generally varies between 740 to $840{ }^{\circ} \mathrm{C}$ for $\mathrm{PbO} / \gamma-\mathrm{Al}_{2} \mathrm{O}_{3}$, between 800 and $840^{\circ} \mathrm{C}$ for $\mathrm{La}_{2} \mathrm{O}_{3} / \mathrm{CaO}$, and between 830 to $850^{\circ} \mathrm{C}$ for CSRIO catalysts. The decrease in selectivity of $\mathrm{C}^{2+}$ and yield compared to fixed bed is due to mass transfer limitations between dilute phase (bubbles) and the condensed phase (emulsion), which is not negligible. In addition, $\mathrm{C}^{2+}$ selectivity and efficiency are affected by the large quantities of gas reverse blend. Both the mass and gas reverse bland are harmful for high selectivity of an intermediate product. 
This is affirmed by high selectivity of hydrogen and the ratio of carbon monoxide to carbon dioxide in a fluidized bed. However, the effect of non-selective gas phase amplified reactions cannot be excluded by a higher porosity compared to the fixed bed.
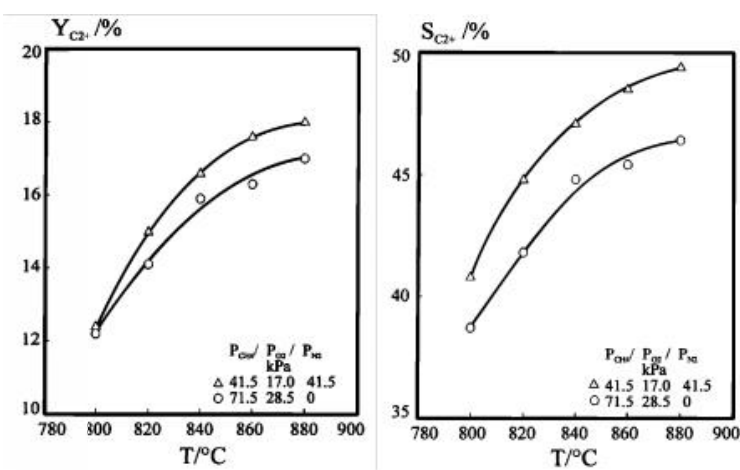

Fig.2. Effect of temperature on selectivity and yield of $\mathrm{C}^{2+}$ in various combinations of feed (Catalyst: $\mathrm{Zr} / \mathrm{La} / \mathrm{Sr}, \mathrm{m}_{\text {cat }}=30 \mathrm{~g}, \mathrm{~d}_{\mathrm{p}}=71-160 \mathrm{~m}, \mathrm{M}_{\text {cat }} / \mathrm{F}=0.3 \mathrm{~g} . \mathrm{s} . \mathrm{mL}^{-1}, \mathrm{u} / \mathrm{u}_{\mathrm{mf}}=10$ )

\section{THE EFFECT OF GAS VELOCITY}

The effect of gas velocity on the efficiency and selectivity of $\mathrm{C} 2+$ is particularly important when we pay attention to the power and scaling. In order to increase the efficiency of spacetime, industrial fluidized bed reactors should work at gas velocities higher than experimental reactors. In addition, for the catalysts $\mathrm{La}_{2} \mathrm{O}_{3} / \mathrm{CaO}[35]$ and $\mathrm{PbO} / \gamma-\mathrm{Al}_{2} \mathrm{O}_{3}[33$ ], increasing gas velocity results in improved selectivity of $\mathrm{C}^{2+}$ The effect is not repeatable when $\mathrm{Zr} / \mathrm{La} / \mathrm{Sr}$ catalysts are used and increasing gas velocity reduces C2+ selectivity (Figures 3-3 and 3-4) [33]. However, due to increasing methane conversion, higher yields can be obtained. Despite lower selectivity, improvements in methane conversion were possible by non-selective transfer of $\mathrm{CO} 2$ and $\mathrm{H} 2 \mathrm{O}$ into $\mathrm{CO}$ and $\mathrm{H}_{2}$ products possible. To explain these effects, the hydrodynamics of the reactors have to be considered.
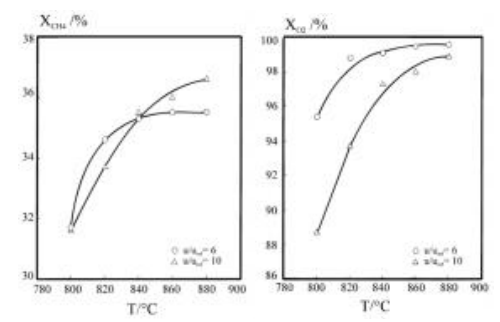

Fig.3. The effect of temperature on the conversion of methane and oxygen for various gas velocities

Four areas can be distinguished in shallow fluidized bed reactor: gas layer, dense, cloudy, and foggy bed. Using shallow bed hydrodynamic model, more detailed explanations for the observed effects are these: 
Raising gas velocity increases the volume of gas layers and porosity in dense part of the bed. This in turn leads to a higher concentration of oxygen, which leads to non-selective reactions. The main products of these reactions are $\mathrm{CO}$ and $\mathrm{H}_{2}$. high porosity of bed is said to be detrimental for $\mathrm{C}^{2+}$ selectivity.
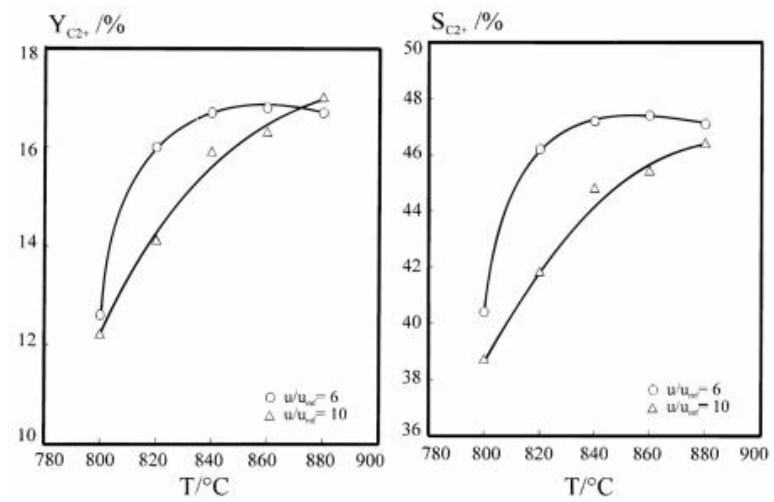

Fig.4. The effect of temperature on $\mathrm{C} 2+$ selectivity and yield for different speeds of gas

\section{THE EFFECT OF BED HEIGHT}

Higher bed results in lower $\mathrm{C}^{2+}$ selectivity and yield. It should be noted that for temperatures higher than $820^{\circ} \mathrm{C}$ no significant differences were observed in oxygen converter. This effect can be explained by either varied hydrodynamic conditions in the oxygen-rich zone or consecutive reactions in the zone without oxygen.

However, the reduction of methane conversion at temperatures higher than $820^{\circ} \mathrm{C}$ indicates that reduction of selectivity of $\mathrm{C} 2+$ is basically done by non-selective oxidation reactions. Since in bubble bed, reverse gas blend is more concentrated, ethylene and ethane can move from the upper part of the bed into the distribution oxygen-rich zone (where they burn) [33]. Lower selectivity of $\mathrm{C} 2+$ by a similar distribution of non-selective products causes low conversions of methane by stoichiometry reasons.
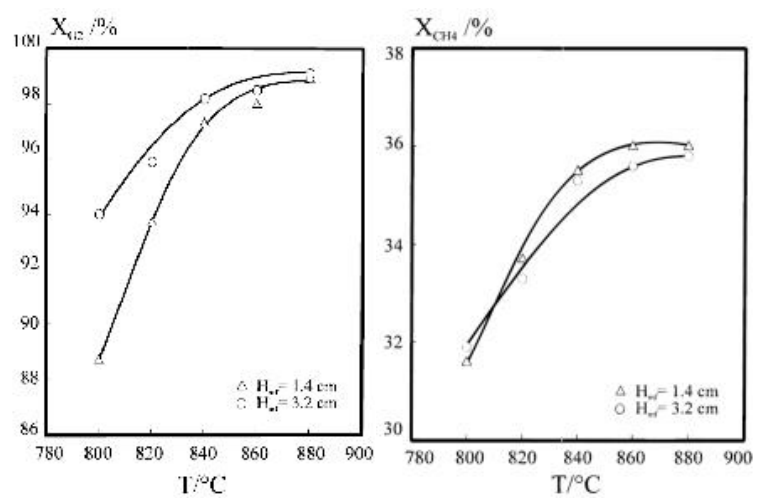

Fig.5. The effect of temperature on the conversion of methane and oxygen for different heights of the bed 
The increased ratio of $\mathrm{CO}$ to $\mathrm{CO}_{2}$ when using higher bed indicates oxidation is with $\mathrm{C}^{2+}$ hydrocarbons reverse blend that can occur in the gas phase. In addition, long residence periods, particularly in emulsion phase of bubble bed, strengthens dehydrogenation of ethane to ethylene, which justifies higher ethylene to ethane ratios and higher selectivity of the hydrogen obtained. The results of bench scale reactors show that a bubble bed would not be a good choice for application of scaling. A large diameter of an industrial reactor strengthens solid rotation and reverse gas blend. In addition, higher beds serve two purposes. Using a distributor of industrial gases would result in lower mass transfer coefficients. A higher bed is also required to achieve complete conversion of oxygen and temperature control by an immersed heat exchanger.
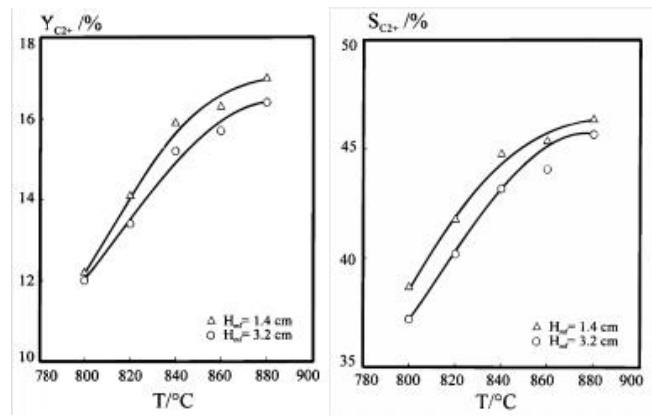

Fig.6. The effect of temperature on selectivity and yield of $\mathrm{C} 2+$ for different bed heights (Catalyst: $\mathrm{Zr} / \mathrm{La} / \mathrm{Sr}, \mathrm{m}_{\mathrm{cat}}=30,70 \mathrm{~g} . \mathrm{u} / \mathrm{u}_{\mathrm{mf}}=10 . \mathrm{d}_{\mathrm{p}}=71-160 \mathrm{~m} . \mathrm{M}_{\mathrm{cat}} / \mathrm{F}=0.3,0.7$ g.s.mL ${ }^{-1} \cdot \mathrm{P}_{\mathrm{CH} 4}=72$

$$
\left.\mathrm{kPa} . \mathrm{P}_{\mathrm{O} 2}=28 \mathrm{kPa}\right)
$$

The bed can be detrimental for $\mathrm{C}^{2+}$ selectivity due to prolonged residence time in the emulsion phase that undergirds conversion by $\mathrm{C}^{2+}$ hydrocarbons vapor. The impact of residence time in fluidized bed reactors has been studied for other systems such as the catalysts CISRO, $\mathrm{La}_{2} \mathrm{O}_{3}$ / $\mathrm{CaO}$. Based on the above results, a common result for active catalysts such as $\mathrm{Zr} / \mathrm{La} / \mathrm{Sr}$, CISRO and $\mathrm{La}_{2} \mathrm{O}_{3} / \mathrm{CaO}$ is that a reactor with a short residence time such as disturbed ground, lifting, or fountain bed will be a preferential option for scaling applications.

\section{THE EFFECT OF PARTICLE SIZE}

Another important parameter that affects both the reaction and hydrodynamic of fluidized bed reactors is particle size $\left(D_{p}\right)$. Therefore, its effect on system performance has been determined for a variety of particle sizes 100-800 m. Figure 7a shows particle size reduction intensifies the reaction. The conversion of methane, oxygen, and $\mathrm{C} 2+$ selectivity often increase by reducing the size of catalyst particles as shown in Figures $7 \mathrm{~b}$-d. Changes in particle size affect the rate of minimum $\mathrm{u}_{\mathrm{mf}}$ as well as mass transfer exchange parameter $\mathrm{k}_{\mathrm{db}}$. However, it is 
important to show that while small particles increase the reactor performance, smaller particle size are difficult to be used in practice because the forces between particles have greater influence on each other than acceleration forces of gravity.
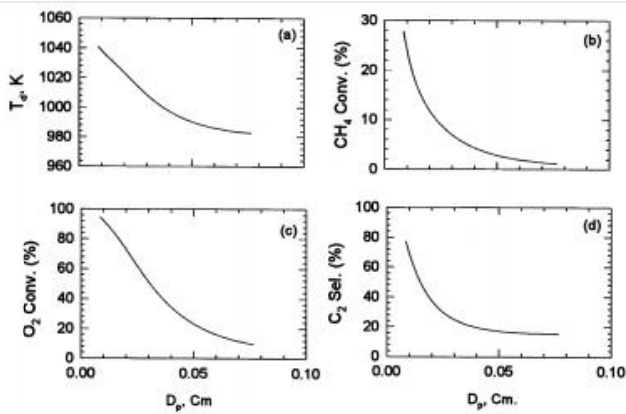

Fig.7. The effect of particle size on a) condensed phase temperature b) methane conversion c)

$$
\mathrm{C}^{2+} \text { selectivity [41] }
$$

\section{THE EFFECT OF ETHANE PRESENCE IN FEED}

In natural gas, ethane exists 5 to $10 \%$ by volume. It is also a preliminary product of oxidative coupling. Therefore, effective use of ethane is essential in making oxidative coupling process economical. A way of using ethane is keeping it in the feed and return flow of methane and converting it to unsaturated compounds in the coupling reactor. in this case, it is necessary to define a conversion percent which is the ratio of the carbon in unsaturated compounds and oxides of carbon (COx) to the total carbon in the feed. The tests have been done with and without methane on for example $\mathrm{Li} / \mathrm{MgO}$ catalyst in a fluidized bed [39].

It is shown that at normal temperatures, the reactor performance improves considering carbon conversion and selectivity of unsaturated compounds.

\section{THE EFFECT OF CATALYST BED DILUTION WITH INERT SOLID ON REACTOR PERFORMANCE}

Considering the works done on oxidative coupling of methane in fluidized bed reactor, it can be assumed that the performance of reactor is controlled by Hydrodynamic effect of fluidized bed on series reactions (including oxidation of ethane and ethylene produced in oxidative coupling reaction of methane to carbon oxides). Another reaction engineering tool to improve the selectivity of the intermediate products when for complex reactions in a fluidized bed reactor is dilution of the catalyst bed with a solid inert. Considering mass transfer between bubble phase and emulsion, bed dilution reduces the intensity of effective reaction [34]. However, the results on the catalyst $\mathrm{La}_{2} \mathrm{O}_{3} / \mathrm{CaO}$ show the contrary of the assumptions. $\mathrm{C}^{2+}$ 
selectivity reduction and methane conversion as well as the increased ratio of ethylene to ethane $\mathrm{CO} / \mathrm{CO}_{2}$ indicate oxygen consumption in the reaction of burning $\mathrm{C}^{2+}$ hydrocarbons.

\section{METHOD OF MAKING CATALYST}

The catalyst used in the experiments conducted in this study is $\mathrm{Mn} / \mathrm{Na}_{2} \mathrm{WO}_{4} / \mathrm{SiO}_{2}$ which was made by dried insemination. For making the catalyst $\mathrm{Mn}(4 \%) / \mathrm{Na}_{2} \mathrm{WO}_{4}(5 \%) / \mathrm{SiO}_{2}$ for the desired percentages, the leading catalyst materials were used. the catalyst was prepared in such a way that the amount of Mn was 4weight percent and Na2WO4 was 5 weight percent. For this purpose, manganese nitrate and sodium tungstate (Merck) and Silica 645Davisil grade (Aldrich) were used. The amount of water to dissolve the salt and be added to Silica was determined according to basic pore volume $\mathrm{SiO} 2(\mathrm{ml} / \mathrm{g} 15 / 1)$. To build $2 \mathrm{~g}$ of the catalyst, the salts were dissolved in 1.2 liters of water. First, manganese salt is dissolved in water and is added in drops so that it can reach all parts of silica.

The product was placed overnight at $130{ }^{\circ} \mathrm{C}$ to dry. Then sodium tungstate salt was dissolved in a specified amount of water and was added to the dried sample. Again, the product was placed overnight at $130{ }^{\circ} \mathrm{C}$ to dry. Finally, the obtained catalyst was calcined for 8 hours at $800{ }^{\circ} \mathrm{C}$.

\section{CHARACTERIZATION OF CATALYSTS}

To determine the characterization of the catalyst, XRD Philips model was used to determine the phases formed in the catalyst.

\section{Investigating Redox catalyst characteristics in transient state}

In order to analyze Redox characteristic of catalyst, transient state system was installed and initial testing was done. In the system, the reaction of Oxidative coupling of methane occurred using GC-MS Thermo Finnegan model Tracer 2340 MS. A series of changes were done on this system to be able to analyze gases simultaneously and be able to study incremental changes in the way of feeding input. Figure 8 shows micro reactors used in this experiment.

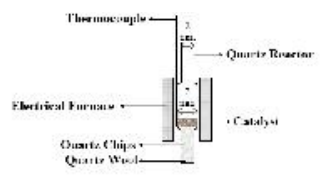

Fig.8. Micro-reactors used for experiments in transient state 


\section{EVALUATION OF CATALYST PERFORMANCE}

Evaluation of catalyst performance includes the effects of temperature, flow rate of feed, and feed compositions. In the experiments carried out, each time only one of the conditions is changed and the others are considered constant. At the start of the study, all the catalysts are at baseline $\left(\mathrm{CH}_{4} / \mathrm{O}_{2}=5\right.$ and $\left.\mathrm{T}=800^{\circ} \mathrm{C}\right)$. Using the analysis, the performance of the catalyst remains in the base condition until reaching stable conditions. For tests of fluidized bed, two amounts of catalysts were used: 2.0 and 3.5 gam. Controlling temperature in a fixed bed is the same as in a fluidized bed. In the first stage, the experiments started with 3.5 grams of catalyst and a feed gas superficial velocity of $4.3 \mathrm{~cm} / \mathrm{s}(478 \mathrm{sccm})$ and the ratio of $\mathrm{CH}_{4} / \mathrm{O}_{2}=1$ to evaluate the effect of temperature changes of the bed at temperature range of $700-850{ }^{\circ} \mathrm{C}$. Then, the experiments were carried out once with superficial velocity of input gas $2.1,4.3$, 6.4 , and $8.6 \mathrm{~cm} / \mathrm{s}$ (flow rated of 240,478,717, and $956 \mathrm{~cm}$ ) at a fixed ratio $\mathrm{CH} 4$ /air= 1 and once with superficial velocity of input gas $4.3 \mathrm{~cm} / \mathrm{s}$ (constant flow rate $478 \mathrm{~cm}$ ) and ratios of 1.4, 1.0 and $\mathrm{CH}_{4} / \mathrm{Air}=0.6$ at a constant bed temperature $850^{\circ} \mathrm{C}$ ( the experiments were repeated under the same conditions in a fixed bed). In the second phase, to study the effect of speed (feed rate) at higher doses, i.e. 10.7 and $12.1 \mathrm{~cm} / \mathrm{s}(1195$ and $1355 \mathrm{~cm})$, the catalyst was reduced to 2.0 grams. In studying the performance of the reactor at different reaction conditions of OCM, the main criterion has been comparing system performance based on the calculated values of the selectivity of products, conversion of $\mathrm{CH}_{4}$, and yield of $\mathrm{C}_{2}$.

\section{Type of reactor}

The reactor used for the tubular reactor reaction was made of quartz. The internal diameter of the main part of the reactor is $30 \mathrm{~mm}$. In order to stop the reactions in the gas phase, input and output of the reactor are made of a twin-tube with an internal diameter of $5 \mathrm{~mm}$ made so that the outputs of the catalyst bed reactors is removed rapidly from the hot zone. In order to control the temperature of the catalyst bed, a quartz tube is embedded in the reactor core for thermocouple to be placed there. Gas distributor is made of quartz and has a diameter of 30 $\mathrm{mm}$ and maximum nominal pore size of 10-16 $\mathrm{m}$. For preheating input feed, the area between gas input part and the area under the distributor is filled with quartz chips. 


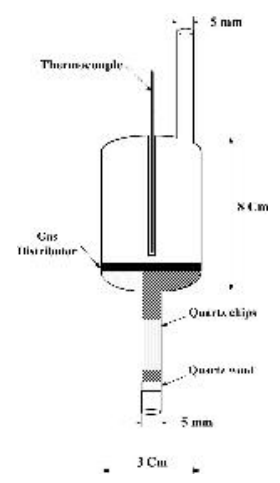

Fig.9. Schematic view of reactor performance test of fluidized bed catalyst

Reactor is placed inside an electric furnace the temperature of which is controlled by a temperature controller depending on the required temperature. In order to monitor the reactor temperature, another thermocouple has been placed between the body of the reactor and the furnace wall. These thermocouples are type $\mathrm{K}, \mathrm{TJ}_{36}$-CAIN-116U-12 produced by OMEGA Company.

\section{System analysis}

Analysis program is done on-line using gas chromatography method in which all the components including reagents and products are simultaneously identified. Mygyrnd. Output products move from the reactor into a Carl 400 device for analysis. The device is equipped with two detectors: FID (Flame Ionization Detector) and TCD, (Thermal Conductivity Detector). In analysis of OCM, FID was used. In FID, H2 and AIR gases are used as carrier gas. FID temperature is set at about $300 \mathrm{oC}$. GC system uses a 10-port valve (V1) and two 6hole valves (V2, V3). The columns operate through Carle-GC program. In this study, column Porapak $\mathrm{N}$ and Molecular sieve 5A were used. All the columns are in a box at $60-55{ }^{\circ} \mathrm{C}$. For more accurate analysis of $\mathrm{CO}$ and $\mathrm{CO} 2$ gases, GC system uses a Methanizer with a Stainless Steel tube that contains catalyst $\mathrm{Ru} / \mathrm{A} 2 \mathrm{O} 3$ and held constant at $410-430{ }^{\circ} \mathrm{C}$. This collection has the ability to convert the mixture of $\mathrm{H} 2$ and $\mathrm{CO}$ or $\mathrm{H} 2$ and $\mathrm{CO} 2$ to methane. The methane is also measurable by FID.

\section{CATALYST PERFORMANCE TEST RESULTS}

\section{Effect of temperature}

To test the effect of temperature on the conversion and selectivity, $3.5 \mathrm{~g}$ catalyst was tested in $478 \mathrm{sccm}$ flow rate $(\mathrm{u}=4.3 \mathrm{~cm} / \mathrm{s})$ with the ratio of $\mathrm{CH} 4 / \mathrm{AIR}=1$ in a fixed bed and fluidized bed. The results of this series of experiments are presented in Figure 10-5. As it can be observed, 
in the temperature range of the experiment, conversion increases steadily conversion in both fixed bed and fluidized bed reactors from 1.85 and $3.32 \%$ to $32 \%$. At the temperature range below $750{ }^{\circ} \mathrm{C}$, conversion in the fixed bed reactor is less than fluidized bed reactor.

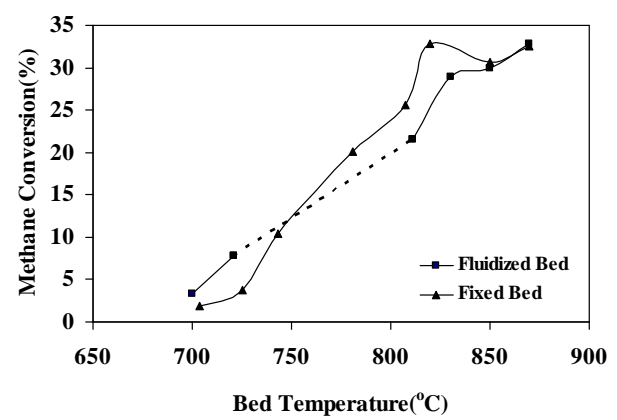

Fig.10. Effect of temperature on the percentage of methane conversion in a fixed bed and

\section{fluidized reactor}

We see that unlike the conversion rate, selectivity showed very little change compared to $\mathrm{C}^{2+}$ products. $\mathrm{C}^{2+}$ products selectivity in the fluidized bed at 700 to $720^{\circ} \mathrm{C}$ increases between $57 \%$ and $66 \%$. At the temperature $850{ }^{\circ} \mathrm{C}$, it is relatively stable and averages $68 \%$. In the aforementioned figure, the trend of selectivity increase of $\mathrm{C}^{2+}$ compounds can also be seen for fixed bed reactor as well as selectivity increases from $37 \%$ to $59 \%$ at the temperature between 700 to $740^{\circ} \mathrm{C}$ and then stays stable at $62 \%$ at $850^{\circ} \mathrm{C}$. However, as the temperature increases to $870{ }^{\circ} \mathrm{C}$, selectivity of $\mathrm{C}^{2+}$ products in both fixed bed and fluidized bed reactors drop to $67 \%$ and $57 \%$, respectively.

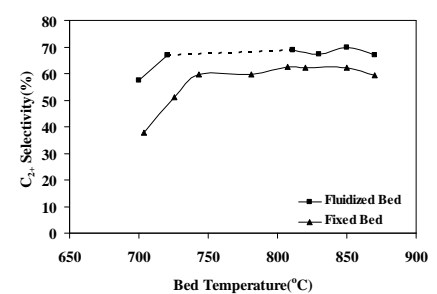

Fig.11. Effect of temperature of catalyst bed on the selectivity of $\mathrm{C} 2+$ products in a fixed bed and fluidized reactor

In general, most catalysts used in OCM process are expected to show increase with temperature, which is primarily due to the reduction of $\mathrm{CO}$ formation from methyl radicals by gas-phase reaction below:

$\mathrm{CH}_{3}^{\bullet}+\mathrm{O}_{2} \longrightarrow \mathrm{CH}_{3} \mathrm{O}_{2}^{\bullet} \longrightarrow \mathrm{CO}, \mathrm{CO}_{2}$

Proxy methyl radical formation $(\mathrm{CH} 3 \mathrm{O} 2 \bullet$ ) which leads to the formation of $\mathrm{CO}$ and $\mathrm{CO} 2$ is not significant at higher temperatures and therefore it is expected that $\mathrm{C} 2+$ selectivity increases as the temperature goes up. However, selectivity decrease at higher temperatures 
observed in some catalysts is perhaps to some extent because of complete combustion of ethane and ethylene in the gas phase or on the catalyst surface at higher temperatures.

\section{The effect of superficial input gas velocity (feed flow rate)}

To evaluate the effect of superficial input gas velocity (feed rate) at a constant temperature of $850 \mathrm{oC}$ and $\mathrm{CH} 4 / \mathrm{Air}=1$, the amount of catalyst was changed from 3.5 to $2 \mathrm{~g}$ so that the high levels of gas velocity could be investigated. Figure 12 shows the changes of methane conversion with increasing input gas superficial velocity for 2 grams of catalyst in a fluidized bed reactor.

As can be observed, in a certain range of flow rates ( $\mathrm{sccm} 240-956)$ or gas inlet velocity (2.1$8.6 \mathrm{~cm} / \mathrm{s})$ conversion rate is almost constant (26\%). However, as input gas velocity increases to $\mathrm{u}=12.1$ (feed rate to $1355 \mathrm{sccm}$ ), up to $6 \%$ reduction in the percentage is observed. In addition, the tests showed that as feed rate increases, selectivity decreases slightly from $68 \%$ (flow rate $240 \mathrm{sccm}$ ) to about $60 \%$ (flow rate $1355 \mathrm{sccm}$ ).

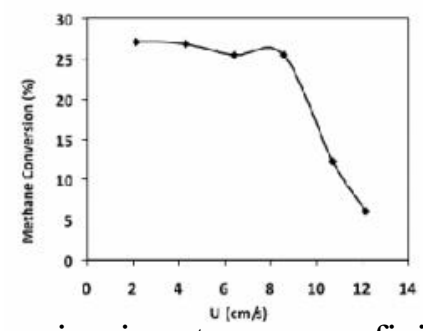

Fig.12. The effect of increasing input gas superficial velocity (feed rate) on methane conversion in a fluidized bed reactor (catalyst weight $=2 \mathrm{~g}$, reaction temperature $=850, \mathrm{CH} 4$ /

$$
\text { Air }=1 \text {, confidence interval }= \pm 1.9 \text { ) }
$$

Product selectivity diagrams are presented in Figures 13 and 14, for 2.0 and 3.5 grams of catalyst, respectively. Considering the figures, it can be found out that the conversion of ethane to ethylene increases with increasing contact time. The increase in contact time, though, causes no perceptible change in the amount of $\mathrm{CO} 2$. The important point about the used catalyst is that ethylene to ethane rate for both the reactors is always greater than one for all residence times, which is an advantage of this catalyst. While, for example, for catalyst $\mathrm{Li} / \mathrm{MgO}$, which is an active and selective catalyst in the process of OCM has the ratio of ethylene to ethane under one in different conditions of reaction. 


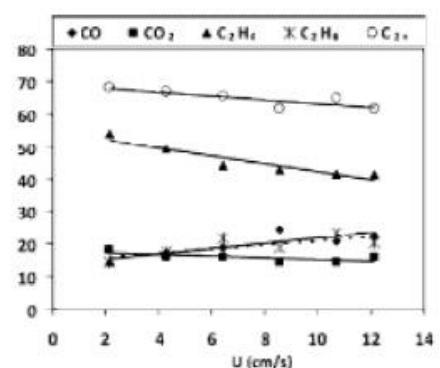

Fig.13. The effect of increasing input gas superficial velocity (feed rate) on the selectivity of products in a fluidized bed reactor (catalyst weight $=2 \mathrm{~g}$, reaction temperature $=850, \mathrm{CH}_{4}$ /

$$
\text { Air }=1 \text {, confidence interval }= \pm 1.7 \text { ) }
$$

Velocity increase increases gas volume and porosity in dense layer of bed, which leads to higher concentrations of oxygen, which strengthens the stages of non-selective reaction and non-selective gas phase reactions.

In other words, compared to fixed bed, OCM reaction requires less volumetric flow rate for oxygen consumption. From these results, it is found out that $\mathrm{C}^{2+}$ selectivity relatively decreases with increasing GHSV and the remaining oxygen in the exhaust gas reduce the $\mathrm{C}^{2+}$ selectivity.

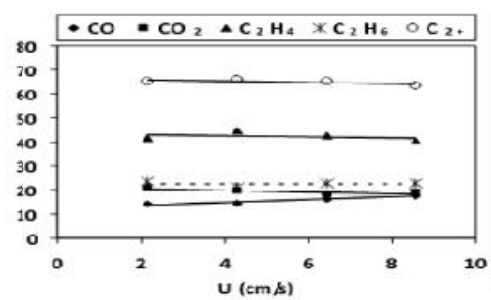

Fig.14. The effect of increasing gas superficial velocity (feed rate) on the selectivity of products in a fluidized bed reactor (catalyst weight $=3.5 \mathrm{~g}$, reaction temperature $=850, \mathrm{CH} 4$ /

$$
\text { Air }=1 \text {, confidence interval }= \pm 1.7 \text { ) }
$$

It has been suggested that non-selective blend of remaining oxygen or non-selective gas phase reactions of $\mathrm{C}^{2+}$ hydrocarbons in a diluted phase impact selectivity of $\mathrm{C}^{2+}$ Therefore, by increasing the feed gas inlet velocity, selectivity of $\mathrm{CO}$ and $\mathrm{H}_{2}$ increase. Some believe high porosity of bed is harmful for $\mathrm{C}^{2+}$ selectivity, which is shown for $\mathrm{Al}_{2} \mathrm{O}_{3}-\gamma / \mathrm{PbO}$.

The process of reducing the amount of $\mathrm{CO}$ produced by increasing contact time can be observed for both 2 and 3.5 grams of the catalyst. The reduction in the amount of CO can be the result of conversion of $\mathrm{CO}$ to $\mathrm{CO}_{2}$ by oxidation or the water-gas-shift reactions. The changes of conversion and selectivity with gas velocity (feed rate) for comparing the yields of 
fixed bed and fluidized bed are shown in figures 15 and 16 . The tests showed that in the same operating conditions of the partial pressure of reactants and catalyst bed temperature, higher conversion rates can be obtained in fixed bed while the selectivity is slightly higher than in fluidize bed.

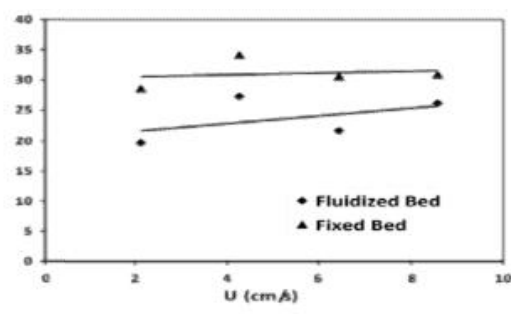

Fig.15. Methane conversion changes at different input gas superficial velocity (feed rate); comparing the performance of a fluidized bed reactor and a fixed bed reactor

Considering the mixing of solid phase in fluidized bed, it can be assumed that in the fluidized bed, the temperature in catalyst bed and the reaction zone is potentially $850^{\circ} \mathrm{C}$. In other words, the changes over the bed are too small. On the contrary, in fixed bed, according to the work done by Lunsford et al. [50 and 51], temperature difference along the fixed bed are very high. In other words, although the temperature is fixed at a point, the average temperature of fixed bed is higher than $850{ }^{\circ} \mathrm{C}$.

\section{CONCLUSION AND RECOMMENDATIONS}

The main purpose of this study was to evaluate the performance of Redox catalysts in the process of oxidative conversion of methane in a fluidized bed reactor and compare the results with the performance of a fixed bed reactor. The catalyst Mn-Na2WO4 / SiO2 was shown to have high activity in the oxidative coupling process of methane. The transient state tests showed that the catalyst has redox properties and its network has an oxygen which can participate in oxidative coupling reaction. According to the results provided, temperature has direct effect on selectivity of network oxygens. This means that at temperature $800{ }^{\circ} \mathrm{C}$, surface oxygens of catalyst network interact and increase selectivity in favor of C2 products. The only effect of temperature is on the rate of movement of network oxygens. After confirmation of Redox property of the catalysts, coupling oxidative process of methane on the catalyst Mn-Na2WO4 / SiO2 was studied in a shallow fluidized bed reactor and fixed bed 
reactor at laboratory scale. During the process OCM in fluidized bed, isothermal conditions which are mainly due to reverse blend of solid phase became achievable.

The highest yield of $\mathrm{C}^{2+}$ obtained, $21.9 \%$, was in a fluidized bed reactor $(\mathrm{u}=4.3 \mathrm{~cm} / \mathrm{s}$ or volumetric flow rate of feed $=\operatorname{sccm} 478$, the temperature of the catalyst bed $={ }^{\circ} \mathrm{C} 870$, Air $/$ $\mathrm{CH}_{4}=1$, and weight of the catalyst $=3.5 \mathrm{~g}$ ).

$\mathrm{C}^{2+}$ products selectivity increases as temperature goes up to 720 degrees for fluidized bed and $740{ }^{\circ} \mathrm{C}$ for fixed bed. For higher temperatures up to $850{ }^{\circ} \mathrm{C}$, it is relatively stable. Increasing input gas velocity (flow rate of feed) to the fluidized bed reactor reduces conversion rate and selectivity of $\mathrm{C}^{2+}$ respectively, from 27.1 percent to $6.1 \%$ and from $67.9 \%$ to $61.5 \%$ (Air/ $\mathrm{CH}_{4}$ $=1$ and catalyst bed temperature $=850{ }^{\circ} \mathrm{C}$ ). the comparison of fixed bed and fluidized bed reactors at different rates (discharges of feed) showed fixed bed reactor has higher conversion and selectivity thanks to its higher average temperature. Reducing the oxygen content in the feed increases the selectivity of $\mathrm{C}^{2+}$ from $55.3 \%$ to $71.6 \%$ and decreases methane conversion from $32.2 \%$ to $25.6 \%$. In total, $\mathrm{C}^{2+}$ yield loss in the fluidized bed compared to a fixed bed is related to non-selective gas phase reactants and reaction products as well as the differences in solid /gas contact in the two types of reactors. In the end, it is suggested that for further investigation of the parameters affecting the performance of a fluidized bed reactor, the effect of particle size should be examined. In addition, considering Redox features of the catalyst, the performance of the catalyst in two-zone fluidized bed reactors should be examined.

\section{REFERENCES}

[1] Amenomiya Y., Birss V., Goledzinowski M., Galuszka J. and Sanger A.R., "Conversion of methane by oxidative coupling”, Catal. Rev.- Sci. Eng., 32(3) (1990) 163-227.

[2] Keller G. E. and Bhasin M. M., "Synthesis of ethylene via oxidative coupling of methane: I. Determination of active catalysts", J. Catal., 73 (1982) 9-19.

[3] Voskresenskaya E. N., Roguleva V. G., and Anshits A. G., "Oxidant activation over structural defects of oxide catalysts in oxidative methane coupling", Catal. Rev. -Sci. Eng., 37(1) (1995) 101-143.

[4] Stansch Z., Mleczko L. and Baerns M., "Comprehensive Kinetics of Oxidative Coupling of Methane over the $\mathrm{La}_{2} \mathrm{O}_{3} / \mathrm{CaO}$ Catalyst”, Ind. Eng. Chem., 36 (1997) 2568-2579.

[5] Santamaria J. M., Eduardo E. M. and Wolf E. E., "Reactor simulation studies of methane oxidative coupling on a sodium/nickel-titanium oxide $\left(\mathrm{NiTiO}_{3}\right)$ catalyst", Ind. Eng. Chem. Res., 30 (6) (1991) 1157-1165. 
[6] Chaouki J., Gonzalez A., Guy Ch. and Klvana D., "Two-phase model for a catalytic turbulent fluidized-bed reactor: Application to ethylene synthesis", Chem. Eng. Sci., 54 (1999) 2039-2045.

[7] Zanthoff H. and Baerns M., "Oxidative coupling of methane in the gas phase. Kinetic simulation and experimental verification”, Ind. Eng. Chem. Res., 29 (1990) 2-10.

[8] Lee J. S. and Oyama S. T., "Oxidative coupling of methane to higher hydrocarbons", Catal. Rev. - Sci. Eng., 30 (1988) 249-280.

[9] Driscoll D. J., Wilson M., Wang J-X., and Lunsford J. H., "Formation of gas-phase methyl radicals over magnesium oxide”, J. Am. Chem. Soc., 107(1) (1985) 58-63.

[10] McCarty J. G., Quinlan M. A., and Sancier K. M., ACS. Div, Fuel Chem. Preps., 33(3) 363 (1988).

[11] Iwamoto M. and Lunsford J. H., "Surface Reactions of Oxygen Ions. 5. Oxidation of Alkanes and Alkenes by $\mathrm{O}_{2}^{-}$on MgO”, J. Phys. Chem., 84 (1980) 3079-3084.

[12] Ito T., Tashiro T., Watanabe T., Toi K., and Ikmoto I., "Activation of methane on the MgO surface at low temperatures”, Chem. Lett., 9 (1987) 1723-1726.

[13] Jones C. A., Leonard J. J., and Sofranko J. A., “The oxidative conversion of methane to

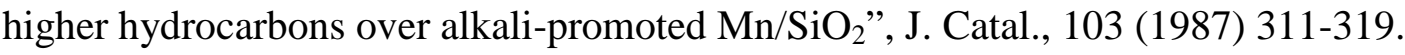

[14] Gaffney A. M., Jones C. A., Leonard J. J., and Sofranko J. A., "Oxidative coupling of methane over sodium promoted praseodymium oxide", J. Catal., 114 (1988) 422-432.

[15] Otsuka K., Jinno K., and Morikawa A., "The catalysts active and selective in oxidative coupling of methane", Chem. Lett., 14(4) (1985) 499-500.

[16] Campbell K. D., Zhang H., and Lunsford J. H., "Methane Activation by the Lanthanide Oxides”, J. Phys. Chem., 92 (1988) 750-753.

[17] Lin C., Campbell K. D., Zhang H., and Lunsford J. H., "Oxidative Dimerization of Methane over Lanthanum Oxide”, J. Phys. Chem., 90 (1986) 534-537.

[18] Yingli B., Kaiji Z., Yutao J., Chiwen T., And Xiangguong Y., "Catalytic oxidative coupling of methane over alkali, alkaline earth and rare earth metal oxides", Appl. Catal., 39 (1988) 185-190.

[19] Otsuka K., Liu Q., Hatano M., and Morikawa A., "Synthesis of ethylene by partial oxidation of methane over the oxides of transition elements with LiCl", Chem. Lett., 16(5) (1986) 903-906.

[20] Otsuka K. and Komatsu T., "Active catalyst in oxidative coupling of methane”, J. Chem. Soc., Chem. Commun., (1987) 388-389. 
[21] Schweer D., Mleczko L. and Baerns M, "OCM in a fixed-bed reactor: limits and perspectives", Catal. Today, 21 (1994) 357-369.

[22] Zeng Y. and Lin Y. S., "Oxygen Permeation and Oxidative Coupling of Methane in Yttria Doped Bismuth Oxide Membrane Reactor”, J. of Catalysis, 193 (2000) 58-64.

[23] Zeng Y., Lin Y. S. and Swartz S. L., "Perovskite-type ceramic membrane: synthesis, oxygen permeation and membrane reactor performance for oxidative coupling of methane", J. of Membrane Science, 150 (1998) 87-98.

[24] Kunni D. and Levenspiel O., "Fluidization Engineering", $2^{\text {nd }}$ Ed., Butterworth Heinemann, (1991) 1-117.

[25] Coudrec J. P., in Fluidization, $2^{\text {nd }}$ ed., Davidson J. F. et al., eds., Chap. 1, Academic Press, New York (1995).

[26] Shirai T., "Fluidized Beds", Kagaku-Gijutsu-Sha, Kanazawa (1958).

[27] Gluckman M. J., Yerushalmi J., and Squires, A. M., in Fluidization Technology, D. L. Keairns, ed., 2, p. 395, McGraw-Hill, New York (1976).

[28] Wilhelm R. H., and Kwauk M., "Fluidization of solid particles", Chem. Eng. Prog., 44 (1948) 201-218.

[29] Geldart D., “Types of gas fluidization”, Powder Technol., 7 (1973) 285-292.

[30] Geldart D., "Homogeneous fluidization of fine powders using various gases and pressures", Powder Technol., 19 (1978) 133-136.

[31] Andorf R. and Baerns M., "Oxidative Coupling of Methane in a Catalytic Fluidized-Bed Reacor”, Stud. Surf. Sci. Catal., 61 (1991) 517-524.

[32] Andorf R., Mleczko L., Schweer D. and Baerns M., "Oxidative Coupling of Methane in a Bubbling Fluidized Bed Reactor”, Can. J. Chem. Eng., 69 (1991) 891-897.

[33] Mleczko L., Pannek U., Niemi V. M. and Hiltunen J., "Oxidative coupling of methane in a fluidized-bed reactor over a highly active and selective catalyst", Ind. Eng. Chem. Res., 35, 54-61 (1996).

[34] Mleczko L., Pannek U., Rothaemel M. and Baerns M., "Oxidative coupling of methane over a $\mathrm{La}_{2} \mathrm{O}_{3} / \mathrm{CaO}$ catalyst. Optimization of reaction conditions in a bubbling fluidized bed reactors", Can. J. Chem. Eng., 74 (1996) 279-287.

[35] Mleczko L., Baerns M., "Catalytic oxidative coupling of methane reaction engineering aspects and process schemes”, Fuel Process. Technol., 42 (1995) 217-248. 
[36] Mleczko L., Rothaemel M., Andorf R. and Baerns M., "Fluidized Bed Reactors Performance for the Catalytic Oxidative Coupling of Methane to $\mathrm{C}_{2+}$ Hydrocarbons. In Fluidization VII”, Potter O. E., Nicklin D.J. Eds., AIChE: New York, (1992) 487-494.

[37] Edwards J. H., Do K. T., Tyler R. J., "Reaction engineering studies of methane coupling in fluidized bed reactors", Catal. Today, 6 (1990 b) 435-444.

[38] Tjatjopoulos G. J., Vasalos I. A. and Haines W. E., "Simulation of high-Velocity Fluidized Bed Reactors for the Oxidative Coupling of Methane. In Preprints of the Symposium Natural Gas Upgrading II", American Chemical Society: Washington DC, 37 (1992) 206-214.

[39] Edwards J. H., Tyler R. J. and White S. D., "Oxidative Coupling of Methane over Lithium-Promoted Magnesium Oxide Catalysts in Fixed-Bed and Fluidized-Bed Reactors", Energy \& Fuels, 4 (1990) 85-93.

[40] Mleczko L., Schweer D., Durjanova Z., Andorf R. and Baerns M., "Reaction Engineering Approaches to the Oxidative Coupling of Methane to $\mathrm{C}_{2+}$ Hydrocarbons", Stud. Surf. Sci. Catal., 81 (1994) 155-164.

[41] Al-Zahrani S.M., "The effects of kinetics, hydrodynamics and feed conditions on methane coupling using fluidized bed reactor”, Catal. Today, 64 (2001) 217-225.

[42] Mleczko L., Andorf R., Baerns M., "Optimization of fluidized bed reactors for the oxidative coupling of methane", prepared for presentation at the AIChE annual meeting in Los Angles, (1991) Unpublished.

[43] Palermo A., Vazques J. P. H., Lee A. F., Tikhov M. S. and Lambert R. M., "Critical influence of the amorphous silica to cristobalite phase transition on the performance of $\mathrm{Mn} / \mathrm{Na}_{2} \mathrm{WO}_{4} / \mathrm{SiO}_{2}$ catalysts for the oxidative coupling of methane”, J. of catal., 177, (1998) 259-266.

[44] Ito T., Wang J. X., Lin C. H., Lunsford J. H., "Oxidative dimerization of methane over a lithium-promoted magnesium oxide catalyst”, J. Am. Chem. Soc., 107 (1985) 5062-5068.

[45] Liu Y., Hou R., Liu X., Xue J. and Li S., "Performance of $\mathrm{Na}_{2} \mathrm{WO}_{4}-\mathrm{Mn} / \mathrm{SiO}_{2}$ catalyst for conversion of $\mathrm{CH}_{4}$ with $\mathrm{CO}_{2}$ into $\mathrm{C}_{2}$ hydrocarbons and its mechanism”, Stud. Surf. Sci. Catal., 119 (1990) 307-311.

[46] Miro E., Santamaria J. and Wolf E. E., "Oxidative coupling of methane on alkali metalpromoted nickel titanate, I. Catalyst characterization and transient studies", J. Catal., 124 (1990) 451-464. 
[47] Choudhary V. R., Rane V. H., "Surface properties of $\mathrm{CaO}$ (or $\mathrm{BaO}$ ) $-\mathrm{La}_{2} \mathrm{O}_{3}-\mathrm{MgO}$ catalysts and their performance in oxidative coupling of methane", J. Chem. Tech. Biotechnol., 69 (1997) 63-69.

[48] Choudhary V. R., Mulla S. A. R., Rane V. H., "Surface basicity and acidity of alkaline earth-promoted $\mathrm{La}_{2} \mathrm{O}_{3}$ catalysts and their performance in oxidative coupling of methane", $\mathrm{J}$. Chem. Tech. Biotechnol., 72 (1998) 125-130.

[49] Maitra A. M., "Critical performance evaluation of catalysts and mechanistic implications for oxidative coupling of methane”, Appl. Catal. A: General, 104 (1993) 11-59.

[50] Wang D., Rosynek M. P., Lunsford J. H., "Oxidative Coupling of Methane over OxideSupported Sodium-Manganese Catalysts", J. Catal., 155 (1995) 390-402.

[51] Pak S., Lunsford J. H., "Thermal effects during the oxidative coupling of methane over $\mathrm{Mn} / \mathrm{Na}_{2} \mathrm{WO}_{4} / \mathrm{SiO}_{2}$ and $\mathrm{Mn} / \mathrm{Na}_{2} \mathrm{WO}_{4} / \mathrm{MgO}$ catalysts", Appl. Catal. A, 168 (1998) 131-137.

\section{How to cite this article:}

Bayanak $M$ and Azimi A. Investigation of activity and selectivity of redox catalysts in oxidative coupling of methane in fluidized bed reactor. J. Fundam. Appl. Sci., 2016, 8(3S), 397-419. 